\title{
Melt Inclusions and Chromite in Lamproites from Smoky Butte, Montana.
}

\author{
Sharygin, V.V.
}

Institute of Mineralogy and Petrography, 630090 Novosibirsk, Russia.

E-mail: sharygin a uiggm.nsc.ru

Smoky Butte is a series of thin dikes and plug-like bodies (K-Ar age - $27 \mathrm{Ma}$ ). All lamproites show evidence of rapid quenching and exhibit the extremely wide variation in modal abundances of phases (olivine, phlogopite, glass, leucite pseudomorphs, etc.) (Mitchell et al., 1987). However, two main rock varieties may be distinguished: olivine-bearing hyalolamproite and holocrystalline sanidine-bearing lamproite. Ca-Sr-Ba-carbonates, barite and davanite represent latecrystallizing phases, filling vugs in the rocks (Velde, 1975; Wagner and Velde, 1986). In general, all Smoky lamproites have similar chemical compositions. They are peralkaline, with high contents of $\mathrm{K}_{2} \mathrm{O}$ (7-11 wt.\%), $\mathrm{MgO}$ (7-9.5 wt.\%), $\mathrm{SiO}_{2}$ (48.5-53.5 wt.\%), $\mathrm{TiO}_{2}\left(5-6.5\right.$ wt.\%), and $\mathrm{P}_{2} \mathrm{O}_{5}$ (up to 3 wt.\%). Primary silicate-melt inclusions have been identified in minerals of both main rock varieties.

\section{Silicate-melt inclusions in minerals}

In glassy lamproites, melt inclusions $(10-50 \mu \mathrm{m})$ were generally found in olivine-2 (Mg\# $0.82-0.86,0.2-0.3 \mathrm{wt} . \% \mathrm{NiO}$, small grains) and in the outer zones of olivine-1 (Mg\# - 0.87-0.92, $0.5-0.8 \mathrm{wt} . \% \mathrm{NiO}$, size $-1-5 \mathrm{~mm}$ ). The phase composition is glass + gas + daughter crystals (typically armalcolite and apatite, rarely diopside and priderite). In some silicate-melt inclusions hosted by olivine, the gas bubbles are partially or completely filled with carbonates (mainly, calcite). Single $\mathrm{Cr}$ spinel crystals and sulfide globules (pentlandite + Ni-rich MSS ? + chalcopyrite) sometimes coexist with melt inclusions in olivine-1. Unfortunately, we were unable to homogenize the silicate-melt inclusions in both olivines due to darkening of the host at $\mathrm{T}>1250^{\circ} \mathrm{C}$. The phase composition of inclusions at this temperature was liquid + armalcolite + fluid. Analcite in hyalolamproites also contain silicate-melt inclusions, but they are inherited from leucite (fresh leucite crystals was only preserved in pyroxene). Inclusions are commonly concentrically-aligned and similar to leucite-hosted inclusions in the Leucite Hills and Oscar Plug rocks (Sobolev et al., 1975; Mitchell, 1991).

In sanidine-bearing lamproites, silicate-melt inclusions $(10-20 \mu \mathrm{m})$ are observed in zoned phlogopite phenocrysts and in groundmass diopside and apatite. Their phase composition is glass + gas + daughter phases. Gas bubbles sometimes contain salt phases. Single crystals of apatite, armalcolite and leucite occur in diopside and phlogopite. Homogenization of the inclusions in apatite occurred at $1220-1230^{\circ} \mathrm{C}$, and of diopside-hosted inclusions - at $1160-1205^{\circ} \mathrm{C}$. Melt inclusions in zoned phlogopite homogenized at temperatures ranging from 1085 to $1210^{\circ} \mathrm{C}$.

The primary inclusion glasses hosted by the Smoky Butte minerals drastically differ in composition from the host rocks with respect to their $\mathrm{SiO}_{2}, \mathrm{TiO}_{2}, \mathrm{MgO}, \mathrm{Al}_{2} \mathrm{O}_{3}, \mathrm{CaO}$, and $\mathrm{P}_{2} \mathrm{O}_{5}$ contents. Residual glasses of olivine-hosted inclusions are characterized by high abundances of alkalis (9-10 wt.\%), $\mathrm{SiO}_{2}$ (63-66 wt.\%), $\mathrm{Al}_{2} \mathrm{O}_{3}$ (11.5-13.5 wt.\%), $\mathrm{BaO}$ (0.7-1.9 wt.\%), $\mathrm{ZrO}_{2}$ and $\mathrm{F}$ (up to 0.4 wt.\%), moderate contents of $\mathrm{TiO}_{2}$ (up to $3.6 \mathrm{wt} \%$ ) and femic components $(\mathrm{MgO}+\mathrm{FeO}+\mathrm{CaO}<6 \mathrm{wt} . \%$ ) (see Figure). They are similar to groundmass glass of Smoky Butte rocks except that the contents of alkalies in the latter is typically low (Mitchell et al., 1987). The moderate $\mathrm{TiO}_{2}$ contents may be explained by early crystallization of armalcolite and priderite. In sanidine lamproites, inclusion glasses in minerals slightly differ from those in hyalolamproite olivine, showing higher contents of $\mathrm{SiO}_{2}$ (up to $70 \mathrm{wt} . \%$ ) and $\mathrm{TiO}_{2}$ (up to $6.5 \mathrm{wt} . \%$ ). Raman spectroscopy of a bubble from melt inclusion in olivine-2 show that fluid is composed of $\mathrm{CO}_{2}\left(26.6\right.$ mole \%) and $\mathrm{N}_{2}$ (73.4 mole \%). Using these values and P-V-T-equations of FLINCOR program, the minimum trapping pressure for this inclusion can roughly be estimated as $1.7 \mathrm{~kb}$ at $1250^{\circ} \mathrm{C}$. 

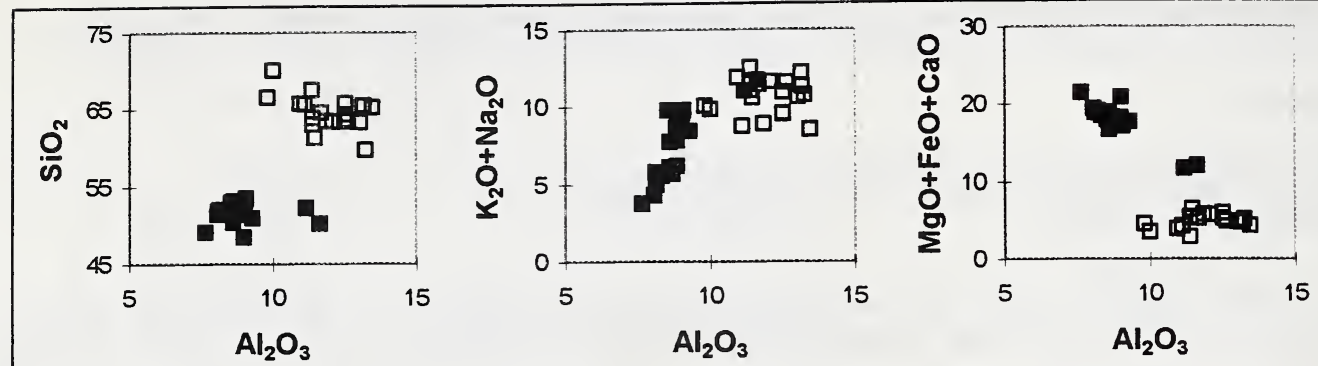

rocks (Velde, 1975; Mitchell et al, 1987);

residual glasses of inclusions in minerals.

\section{Chromite inclusions in olivine}

As described above, the $\mathrm{Cr}$-spinel inclusions form independent euhedra (up to $30 \mu \mathrm{m}$ ) in olivine-1 only. Single crystals have homogeneous composition and are characterized by high $\mathrm{Cr}_{2} \mathrm{O}_{3}$ (53-56 wt.\%), $\mathrm{TiO}_{2}$ (4.5-5.7 wt.\%), $\mathrm{NiO}$ (0.1-0.5 wt.\%), $\mathrm{Fe}^{2+} /\left(\mathrm{Fe}^{2+}+\mathrm{Fe}^{3+}\right)=0.7-0.8$, moderate $\mathrm{Mg} /\left(\mathrm{Mg}+\mathrm{Fe}^{2+}\right)=0.4-0.6$ and low $\mathrm{Al}_{2} \mathrm{O}_{3}(1.8-2.9$ wt.\%) (see Table). Calculations based on Fabries (1979) and Ballhaus et al. (1991) show that equilibrium temperature ranges from 867 to $1106^{\circ} \mathrm{C}$ for the chromite-olivine pair and $\mathrm{fO}_{2}$ values are above QFM buffer on 1-2 log. unit.

On the basis of petrological evidence, the Smoky Butte lamproites are interpreted to represent rocks formed from primitive relatively $\mathrm{SiO}_{2}$-rich mantle-derived magma. This magma ascended rapidly and crystallized at high temperature (Mitchell et al., 1987). The presence of armalcolite, and also sulfide globules and $\mathrm{Cr}$-spinel with low $\mathrm{Fe}^{3+}$ content evidence the reduced state for initial magma at its early crystallization stages. According to experiments of Friel et al. (1977) and Medvedev (1996), armalcolite is stable at low $\mathrm{fO}_{2}\left(<10^{-9.5}\right.$ atm $)$ and $\mathrm{T}>1200^{\circ} \mathrm{C}$. Thus, the initial magma during the early crystallization of the Smoky Butte lamproites (before sanidine formation) was near peralkaline and evolved towards gradual depletion in $\mathrm{P}_{2} \mathrm{O}_{5}, \mathrm{TiO}_{2}, \mathrm{CaO}, \mathrm{MgO}, \mathrm{FeO}$ with enrichment in $\mathrm{SiO}_{2}$, alkalis, $\mathrm{Al}_{2} \mathrm{O}_{3}, \mathrm{BaO}, \mathrm{ZrO}_{2}$ (see Figure). Probably, mass crystallization of sanidine led to the increase of alkalis, $\mathrm{BaO}, \mathrm{CaO}, \mathrm{FeO}, \mathrm{MgO}, \mathrm{TiO}_{2}$ and the decrease of $\mathrm{Al}_{2} \mathrm{O}_{3}$ in residual melt. This evolutionary trend resulted in formation of K-Ti-richterite, magnesioarfvedsonite and davanite on the late stages. In the course of evolution, fluid acquired progressively higher contents of salt components that led to late-magmatic or post-magmatic crystallization of $\mathrm{Ca}-\mathrm{Ba}-\mathrm{Sr}$-carbonates and barite. In general, evolution of initial magma for the Smoky Butte rocks is similar to that of melts parental for lamproites from W.Kimberley, Leucite Hills and other localities (Sobolev et al., 1989; Solovova et al., 1989; Salvioli-Mariani and Venturelli, 1996; Sharygin, 1997).

\section{References}

Ballhaus, C., Berry, R.F., and Green, D.H., 1991, High pressure experimental calibration of the olivine-orthopyroxenespinel oxygen geobarometer: implications for the oxidation state of the upper mantle: Contrib. Mineral. Petrol., 107, p. $27-40$.

Fabries. J., 1979, Spinel-olivine geothermometry in peridotite from ultramafic complexes: Contrib. Mineral. Petrol., 69, p.329-336.

Friel, J.J., Harker, R.I., and Ulmer, G.C., 1977, Armalcolite stability as a function of pressure and oxygen fugacity: Geochim. Cosmochim. Acta, 41, p. 403-410.

Medvedev, A. Ya., 1996, Synthetic armalcolite and pseudobrookite: Mineral. Mag., 60, p. 347-353.

Mitchell, R.H., 1991, Coexisting glasses occurring as inclusions in leucite from lamproites: examples of silicate liquid immiscibility in ultrapotassic magmas: Mineral. Mag., 55, p. 197-202.

Mitchell, R.H., Platt, R.G., and Downey, M., 1987, Petrology of lamproites from Smoky Butte, Montana: J. Petrol., 28. p. 645-677. 
Salvioli-Mariani, E., and Venturelli, G., 1996. Temperature of crystallization and evolution of the Jumilla and Cancarix lamproites (SE Spain) as suggested by melt and solid inclusions in minerals: Eur. J. Mineral., 8. p. 10271039.

Sharygin, V.V., 1997, Evolution of lamproites suggested by inclusians in minerals: Russian Geol. Geophys., 38 (1), p. 136-147.

Sobolev, A.V., Sobolev, N.V.. Smith. C.B., and Dubessy, J., 1989, Fluid and melt composition in lamproites and kimberlites based on study of inclusions in olivine:, Geol. Soc. Austr. Spec. Publication, 14(1). p. 220-240.

Sobolev, V.S., Bazarova, T.Yu., and Yagi, K., 1975. Crystallization temperature of wyomingite from Leucite Hills: Contrib. Mineral. Petrol., 49. p. 301-308.

Solovova, I.P., Girnis A.V., Kogarko. L.N., et al., 1989, Geochemical peculiarities of Prairie Creek lamproites based on data of study of microinclusions in olivines: Geochem. Intern, 27 (5), p. 65-74.

Velde, D., 1975, Armalcolite-Ti-phlogopite-diopside-analcite-bearing lamproites from Smoky Butte, Garfield County, Montana: Amer. Mineral., 60, p. 566-573.

Wagner, C. and Velde, D., 1986, Davanite, $\mathrm{K}_{2} \mathrm{TiSi}_{6} \mathrm{O}_{15}$, in the Smoky Butte (Montana) lamproites: Amer. Mineral., 71, p. 1473-1475.

Table.

Chemical composition (wt. \%) of chromite inclusions and host olivines from glassy lamproites at Smoky Butte (Montana).

\begin{tabular}{|c|c|c|c|c|c|c|c|c|c|c|c|}
\hline$n$ & 2 & 1 & 1 & 1 & 1 & 1 & 1 & 2 & 2. & 3 & 2 \\
\hline \multicolumn{12}{|l|}{ Cr-spinel } \\
\hline $\mathrm{TiO}_{2}$ & 4,84 & 5.18 & 4,78 & 4,70 & 4,80 & 5,70 & 4,65 & 4.75 & 4,87 & 4,66 & 4,63 \\
\hline $\mathrm{Cr}_{2} \mathrm{O}_{3}$ & 54,56 & 53,74 & 55,44 & 54,30 & 54,67 & 52,86 & 54,25 & 55,56 & 55.45 & 54,97 & 55,78 \\
\hline $\mathrm{V}_{2} \mathrm{O}_{3}$ & 0,12 & 0.18 & 0.13 & 0,15 & 0,16 & 0,22 & 0,14 & 0,12 & 0,15 & 0,13 & \\
\hline $\mathbf{A l}_{2} \mathbf{O}_{3}$ & 2,57 & 1,81 & 2,82 & 2,62 & 2,68 & 1,74 & 2,66 & 2,73 & 2,86 & 2,68 & 2,51 \\
\hline $\mathrm{FeO}_{\mathrm{t}}$ & 25.95 & 29.55 & 21.91 & 26.76 & 24,31 & 27,86 & 24.75 & 21.68 & 21.76 & 24.68 & 22,80 \\
\hline MnO & 0.21 & 0,32 & 0,10 & 0,24 & 0,14 & 0,25 & $0,17^{\circ}$ & 0,11 & 0,10 & 0,20 & 0.19 \\
\hline MgO & 10,27 & 8.19 & 12,97 & 9,42 & 11.53 & 9,52 & 11.35 & 13,47 & 13.00 & 11,06 & 13.04 \\
\hline $\mathrm{NiO}$ & 0.28 & 0,13 & 0,42 & 0,25 & 0,40 & 0,30 & 0,44 & 0,47 & 0.42 & 0,37 & 0,46 \\
\hline $\mathrm{ZnO}$ & 0,18 & 0.19 & 0,10 & 0.22 & 0.15 & 0.22 & 0.19 & 0.10 & 0.16 & 0,15 & \\
\hline Total & 98.96 & 99,28 & 98,67 & 98,66 & 98,84 & 98,68 & 98.59 & 98,98 & 98,75 & 98,90 & 99,41 \\
\hline FeOcal & 20,26 & 23.77 & 16.07 & 21.30 & 18.26 & 21.86 & 18.22 & 15,31 & 16,07 & 18.83 & 15.99 \\
\hline $\mathrm{Fe}_{2} \mathrm{O}_{3} \mathrm{cal}$ & 6,32 & 6,43 & 6,50 & 6,07 & 6,72 & 6,67 & 7,25 & 7,08 & 6,32 & 6,51 & 7,57 \\
\hline $\mathrm{Mg} /\left(\mathrm{Mg}+\mathrm{Fe}^{2+}\right)$ & 0.47 & 0.38 & 0,59 & 0,44 & 0.53 & 0.44 & 0,53 & 0,61 & 0.59 & 0,51 & 0,59 \\
\hline $\mathrm{Fe}^{2+} /\left(\mathrm{Fe}^{2+}+\mathrm{Fe}^{3+}\right)$ & 0.78 & 0.80 & 0.73 & 0,80 & 0.75 & 0.78 & 0,74 & 0,71 & 0,74 & 0.76 & 0.70 \\
\hline $\mathrm{Cr} /\left(\mathrm{Al}+\mathrm{Cr}+\mathrm{V}+\mathrm{Fe}^{3+}+\mathrm{Ti}\right)$ & 0,79 & 0,79 & 0.79 & 0,79 & 0,78 & 0,78 & 0,78 & 0,78 & 0,79 & 0,79 & 0,78 \\
\hline $\mathrm{Al} /\left(\mathrm{Al}+\mathrm{Cr}+\mathrm{V}+\mathrm{Fe}^{3+}+\mathrm{Ti}\right)$ & 0,06 & 0.04 & 0,06 & 0.06 & 0,06 & 0.04 & 0,06 & 0,06 & 0,06 & 0,06 & 0,05 \\
\hline $\mathrm{Fe}^{3+} /\left(\mathrm{Al}+\mathrm{Cr}+\mathrm{V}+\mathrm{Fe}^{3+}+\mathrm{Ti}\right)$ & 0,09 & 0,09 & 0,09 & 0,08 & 0.09 & 0,09 & 0,10 & 0,09 & 0,09 & 0,09 & 0,10 \\
\hline \multicolumn{12}{|l|}{ Host olivine } \\
\hline Fo & 89,52 & 88,29 & 88,58 & 88,22 & 90,16 & 87,55 & 87,74 & 90,98 & 88,84 & 89,24 & 90,84 \\
\hline $\mathbf{F a}$ & 9,43 & 10,96 & 10,44 & 10,91 & 8,82 & 11,57 & 11,45 & 8,05 & 10,29 & 9,77 & 8,22 \\
\hline $\mathrm{Mn}_{2} \mathrm{SiO}_{4}$ & 0,15 & 0,17 & 0,18 & 0.19 & 0,14 & 0,22 & 0,18 & 0,11 & 0,16 & 0,16 & 0,10 \\
\hline $\mathrm{Ca}_{2} \mathrm{SiO}_{4}$ & 0,17 & 0,21 & 0,22 & 0,22 & 0,18 & 0.22 & 0,19 & 0,16 & 0.17 & 0,17 & 0,13 \\
\hline $\mathrm{Ni}_{2} \mathrm{SiO}_{4}$ & 0,73 & 0,38 & 0,58 & 0,46 & 0.69 & 0.44 & 0,45 & 0,71 & 0,55 & 0,66 & 0,70 \\
\hline $\mathrm{T},{ }^{\circ} \mathrm{C}$ * & 1145 & 867 & 1106 & 920 & 960 & 952 & 1055 & 1038 & 1097 & 971 & 1027 \\
\hline $\mathrm{D} \log f \mathrm{O}_{2}$ ** & 1,09 & 1,45 & 1,15 & 1,23 & 1,70 & 1,34 & 1,28 & 1,81 & 1,13 & 1,45 & 1,91 \\
\hline
\end{tabular}

* - Fabries, 1979; ** - Ballhaus et al., 1991 (values respect to QFM buffer). 